\title{
The civilizational value of a contract
}

\author{
Mikhail Fedorovich Kazantsev*
}

Department of law, Institute of Philosophy and Law of the Ural Branch of the Russian Academy of Sciences, Yekaterinburg, Russia

\begin{abstract}
The article reveals the civilizational value of a contract as a social phenomenon (legal and non-legal). The contours of the general theory of contract are outlined; the concept of contract as an act of will is formulated, its nature as the most important social regulator is revealed. The article describes the role of a contract as an irreplaceable means of interaction between people, whose civilizational value is determined by the nature of a contract as an act expressing the common binding will of persons who perform it in their own interests. Values such as freedom, democracy, civil society, and human rights are inextricably linked with a contract. The level of contractual freedom is a manifestation and indicator of freedom of a person and society as a whole. The significance of a contract in the legal system is due to the fact that it is the most important legal regulator. The significance of contractual regulation lies in the fact that relations between legally equal subjects cannot be settled only by means of contracts. Contract law is the right of a free person. Thanks to the contract, free people create law for themselves. Law is created by citizens and legal entities through the conclusion of contracts.
\end{abstract}

\section{Introduction}

The value of a contract in the legal field is great. In civil law, the contract is one of the supporting structures. The same is true for labor and international law. The role of contract is growing in other branches of law. The contract is studied by legal science. The literature on legal contracts is extensive [1-6].

Lawyers are unaware of the existence of non-legal contracts or deny them as a phenomenon. However, there are non-legal contracts which quantitatively prevail over legal contracts. The contract is the most important social phenomenon that permeates all spheres of society. The phenomenon of a contract can be defined from the legal, economic, social, cultural and philosophical perspectives. From the non-legal side, the contract is little studied [7-9]. Since contracts are not limited to legal ones, the contract should be studied not only from a purely legal point of view, but also from a general point of view. In other words, it is necessary to develop a general theory of contract.

An important issue in the general theory of contract is its social value.

\section{Definition and types of contract}

The starting point of the general theory of contract are the concept and classification of contracts.

The contract is an act that (1) is committed (concluded) by two or more subjects (parties), (2) who express their agreed (general) will. It is (3) is aimed at regulating relations between the parties.
The generic concept is the concept of an act (volitional act), which can be defined as the will of the subject (s), which has a specific purpose.

A concept subordinate to the contract a unilateral act.

The unilateral act is an act that (1) is committed by one or several subjects acting as one party, (2) expresses their unilateral will and (3) is aimed at regulating the relations of other subjects or also with the participation of the subject who committed the act.

It is necessary to dwell on the essential features of the contract as a type of act.

First, the contract is always concluded by two or more subjects who act as different parties to the contract.

Regardless of the number of subjects representing a party, they act on one side and are opposite to the other side (other parties) of the agreement. The nature of subjects as parties is well manifested when comparing the contract with an act adopted by several subjects. The latter is made by two or more subjects. But they do not act in relation to each other as opposite sides. On the contrary, making a joint act, they act as one party, directing the regulatory impact on other subjects.

Secondly, the contract expresses the agreed will of the subjects (parties) who have concluded it.

The agreed (common) will of the parties to the contract is the most significant characteristic of the contract. The different wills of the subjects (parties) merge into a single common agreed will, although the interests may be different. The agreement is not a set of expressions of the will of the parties. It is the result of an agreement of wills, a general agreed expression of the will, or an act expressing the agreed will of the parties.

A contract as an act of will can be expressed in a document or in another form. In jurisprudence (in the

Corresponding author: kazan.m@mail.ru 
minds of lawyers), the act as an expression of will and its documentary form merge so much that they practically do not differ, do not separate from each other, are perceived as a single whole. However, an act (as an expression of will), including a contract, and a document are closely related, but different objects (phenomena). The contract is an ideal object. A document is a material object. The document acts as a material expression (shell) of the contract as an act.

Thirdly, the contract is aimed at regulating relations between the parties who concluded it.

Any contract is aimed at regulating public relations. A feature of the contract as a regulator of public relations is that it is aimed at regulating the relations between the parties to the contract. Unlike the contact, the one-sided act is aimed at regulating the relations of other subjects (in some cases with the participation of the subject who has committed the unilateral act). The contract is a powerful social regulator. Properties of the contract as a means of regulating social relations and behavior have been described in $[10$, p. $254 ; 11$, p. $397-413 ; 12]$; in recent years they have received a monographic development [13].

Contracts can sub-divided into legal and non-legal contracts. The classification of contracts is most important.

The legal contract is a contract that is aimed at the legal regulation of relations between the parties or with their participation and is ensured with the possibility of state coercion.

The illegal contract is a contract that is aimed at illegal regulation of relations between the parties or with their participation and is not ensured with the possibility of state coercion.

Legal contracts (civil, labor, etc.) are a traditional object of research in branch legal sciences. The development of the general theory of legal contract is underway. The same cannot be said about illegal contracts. Therefore, it is important to provide their brief description.

The daily life of people, activities of government bodies, officials, political parties, and other public entities are permeated with numerous agreements of non-legal nature. Moreover, in quantitative terms, nonlegal contracts dominate over the legal ones.

Non-legal agreements can be subdivided by the sphere of public life in which they regulate the relations (behavior) of subjects who concluded them: political, everyday, and production contracts. The above division does not pretend to be a strict scientific classification of non-legal contracts. It is an illusory incomplete list that helps to get an idea of this group of agreements.

The political non-legal agreement is a non-legal agreement aimed at regulating non-legal relations (behavior) in the political sphere, i.e. in the sphere of public life related to the activities of government bodies, political parties, movements, social and political organizations and groups.

Examples of political contracts are package agreements of factions in the State Shock Duma on the distribution of leading posts, agreements of political parties on the creation of inter-party blocs, agreements concluded within the electoral technologies (agreements between a presidential candidate and voters). One of the last notable examples of a political agreement that was widely discussed in the media is the Public Agreement "Elections-2003", signed on August 22, 2003 in Moscow by representatives of political parties, unions and associations of specialists in mass media and political technologies (a total of about forty).

The everyday non-legal contract is a non-legal contract aimed at regulating non-legal relations (behavior) in the everyday life, i.e. in the public nonproduction life, including the satisfaction of material needs for food, clothing, housing, health maintenance, development of spiritual benefits by a person, culture, human communication, sports, entertainment.

A very large number of everyday contracts are concluded, since any agreement in the household sphere (on visiting theaters, fishing, etc.) is nothing more than an everyday contract. An agreement between sports teams on a game result of is also an everyday contract. The group of everyday contracts includes contracts in personal relations, including those with a pronounced moral, ethical and emotional orientation, in particular, an agreement between a girl and a boy (including in the form of a mutual oath) on keeping fidelity to each other, while the young man is in the army.

The non-legal production contract is a non-legal contract aimed at regulating non-legal relations (behavior) in the production sphere, i.e. in the sphere of public life associated with socially useful labor in the national economy.

Production contracts mediate business, service relationships that develop "at work". These include agreements between heads of departments on the procedure for the joint execution of production tasks, and agreements between a boss and a subordinate according to which if the employee achieves a certain production result, the boss will increase his wages.

In connection with the consideration of unlawful treaties, especially after the mention of "Elections-2003" as a political Social contract, it is appropriate to raise the question of what is the nature of the social contract, about which such famous thinkers wrote as Grotius, Hobbes, Spinoza, Locke and in particular Rousseau, with whose name the social contract, in fact, is associated. Rousseau himself, setting out the essence of the doctrine of the social contract, used characteristic legal terminology: "To find a form of association that by all means protects and secures the personality and property of each of its members ... - this is the main task, the solution of which is given by the Social Contract. The clauses of this social contract are so precisely established by the very nature of the act that the slightest change would render them vain and invalid; ... if we discard from the social contract everything that does not constitute its essence, we will see that it boils down to the following proposition: each of us gives his personality to the common possession and submits all his power to the supreme command of the common will; and 
in the general organism we receive each member as an inseparable part of the whole" [14, p. 13-14].

From the above quotation and the Rousseau's treatise as a whole, it follows that a social contract is thought of as an agreement between people on the creation of a common organism (state) with the endowment of it with supreme power, to which the members of the common organism are subordinate.

Understood in this way, a social contract may well be regarded as a contract, since all the signs of a contract are inherent in it: it is an act (Rousseau himself characterizes a social contract as an act); there are parties - people (individuals); it expresses the agreed will of these people; it is aimed at regulating relations (behavior) between people, namely, relations for the creation of a collective entity, as well as the relationship of members of this collective entity, including with its supreme power.

However, in reality, a social contract (precisely as a contract in the strict sense of the word) has never been concluded either orally (including in the form of tacit consent), or, even more so, in writing. Still, the conclusion of an agreement between all people is practically impossible, especially with such a serious goal.

Thus, a social contract is conceivable only as a purely theoretical construction expressing the idea of universal consent and underlying the philosophical and legal doctrine explaining the emergence of the state and state power on the basis of an agreement between people.

The very idea of harmony in society, harmony between society and government is very popular and is often adopted by the government, political forces, individual politicians, political technologists. And then, from time to time, real documents appear under the name "social contract", one of which is the previously mentioned Public Contract "Elections-2003".

\section{Nature of the civilizational value of a contract}

The civilizational value is a social value that is significant for the development and preservation of civilization.

The contract has a civilizational value. The civilizational value of the contract is due to its regulatory nature. The contract is an irreplaceable social regulator, an irreplaceable means of social interaction between people, a means of autonomous self-regulation of relations between them. People and society cannot live without a contract. If the contract disappears, civilization will also collapse.

The civilizational value of the contract is manifested in its interaction with other social regulators. There are two main regulators with the help of which the social regulation is carried out - a contract and an order (or a unilateral act). The contract and the order interact and complement each other. The order regulates subordinate relations, that is, relations between non-equal subjects, in which one subject has power over another one. The contract regulates relations between equal subjects coordination relations. In such relationships, one subject cannot order the other. Equal entities can regulate relations between themselves by concluding an agreement.

The civilized society cannot exist without social regulation of relations between people (individuals, collectives, organizations). Social regulation cannot be carried out without a contract. This circumstance explains the social value of the contract in its highest manifestation - the civilizational value.

Other social regulators, including law, also have social value. The problem of the social value of law was studied by S.S. Alekseev [15]. He wrote that "law is one of the few phenomena of modern civilization, which has received general recognition as an indispensable condition for the normal existence of people, a phenomenon of the primordial civilizational order, achievements of mankind, its culture. It is destined for an optimistic future - it passes into the new, third millennium and is called upon to continue to play a worthy, highly significant role in the life of the human community. " [16, p. 471].

\section{Manifestations of the civilizational value of a contract}

Values such as freedom, democracy, civil society, and human rights are inextricably linked with the contract. The level of contractual freedom is a manifestation and indicator of the freedom of a person and society as a whole. From the functional point of view, the contract is a legal means, without which it is impossible to develop civil society.

The contract is inherent in all social and legal systems, all state regimes. But if we compare the totalitarian and democratic regimes, it becomes evident that in totalitarian society the role of a contract is belittled, and, conversely, in civil society, the contract is socially and legally significant and a popular and effective legal means.

The contract has a great communication value. Using contracts, people, organizations, authorities, governments (social subjects) enter into various relations with each other, determining their nature and content. Billions of contracts are concluded every day. Each person concludes at least one contract per day (of course, not every day).

In terms of their social value, both legal and nonlegal contracts are important. Nevertheless, the most significant social ties are mediated by legal contracts, the most massive of which are civil ones. Due to these contracts, people buy and sell apartments, cars, televisions, and sausage. By concluding legal contracts, citizens create law for themselves. Such contractual lawmaking of citizens is comparable to the direct lawmaking carried out during referendums [17, p. 122].

Contractual regulation is an effective means of resolving conflicts, because the contract is a product of the conflicting parties rather than imposed from outside. The peacekeeping role of the contract is due to the fact 
that in both public and private law spheres, there are contracts focused on peacekeeping functions - a peace contract (a public-law international contract by means of which the state of war ends, state borders change, other political, military and economic issues are resolved) and an amicable contract (a civil law agreement, through which, through mutual concessions, the ambiguity, doubtfulness or controversy of legal relations between the parties are eliminated ). Iering considered a peace deal to be the most correct way to resolve disputes [18, p. 27]. Competence contracts are also an effective means of resolving conflicts. They demonstrate the potential of a contract as an instrument for resolving differences between government bodies in the federal relations. It was the federal contract that at the beginning of 1992 was able to suspend the disintegration processes in the Russian Federation. It was the agreement between the Russian Federation and the Republic of Tatarstan on the delimitation of jurisdictions in early 1994 that could weaken the tight knot of contradictions.

\section{Conclusion}

From a broad social standpoint, the contract is an irreplaceable means of interaction between people, whose civilizational value is due to its nature as an act expressing the common binding will of persons who perform it in their own interests.

The value and significance of the legal and civil law contract in the legal system is due to the fact that the contract is the most important legal regulator and an administrative non-normative legal act. The importance of contractual regulation is due to the fact that some relations cannot be settled otherwise than by means of a contract (relations between legally equal subjects). The scope of contractual regulation can narrow under the economic, social, and political factors, but it can never disappear.

Contract law is the right of a free person. Thanks to the contract, free people create law for themselves. It is the law created by citizens and legal entities through the conclusion. This is true private law.

\section{References}

1. V.M. Nechaev, Contract theory, Legal Bulletin, 10, 242-265 (1888)

2. R.O. Khalfina, The meaning and essence of the contract in the Soviet socialist civil law (Publishing house of the Academy of Sciences of the USSR, Moscow, 1954) $240 \mathrm{p}$.

3. M.I. Braginsky, V.V. Vitryansky, Contract Law: General Provisions (Statut, Moscow, 1997) 682 p.
4. M.F. Kazantsev, On the question of the general theory of a legal contract, in: Scientific Yearbook of the Institute of Philosophy and Law of the Ural Branch of the Russian Academy of Sciences, issue 1, pp. 179-196 (1999)

5. G.H. Tritel, The law of contract. Tenth Edition (Sweet \& Maxwell, London, 1999) XCIVI, 1016 p.

6. D.Yu. Poldnikov, Institute of the contract in the legal science of Western Europe XI-XVIII centuries: textbook (Higher School of Economics, Moscow, 2013) $368 \mathrm{p}$.

7. V.L. Tambovtsev, Introduction to the economic theory of contracts (INFRA-M, Moscow, 2004) 144 p.

8. T.K. Primak, Philosophical, political and legal aspects of the development of the contract, Philosophy of law (Rostov-on-Don: Rostov Law Institute of the Ministry of Internal Affairs of Russia), 1, 86-90 (2008)

9. V.V. Zalessky, Philosophy of the contract (the law of dynamic equilibrium), Journal of Russian law, 8, 105-111 (2004)

10. I.A. Pokrovsky, The main problems of civil law (Statut, Moscow, 2001) 354 p.

11. E.-J. Mestmaecker, Recht und oekonomisches Gesetz - Ueber die Grenzen von Staat, Gesellschaft und Privatautonomie. 2. Auflage. (Baden-Baden: NomosVerlagsgesselschaft, 1984) 925 p.

12. W. Flume, Rechtgeschaft und privatautonomie, Hundert jahre deutsches rechtsleben: Festschrift zum hundertjahrigen bestehen des deutschen juristentages 1860-1960 (Bandi. Verlag C.F. Muller Karlsruhe, 1960) pp. 135-151.

13. M.F. Kazantsev, Contractual regulation: A civilistic concept. 2nd ed. (Yurayt, Moscow, 2020) 394 p.

14. J.-J. Rousseau, Social contract, or principles of state law (Publishing S. Skrimunt, Moscow, 1906) 134 p.

15. S.S. Alekseev, The social value of law in Soviet society (Yurid. lit., Moscow, 1971) $224 \mathrm{p}$.

16. S.S. Alekseev, Law on the Threshold of the New Millennium: Some Trends in the World Legal Development - the Hope and Drama of the Modern Era, in: Collected Works. In 10 volumes (Statut, Moscow, 2010) vol. 5, pp. 295-544.

17. V.N. Rudenko, Direct Democracy: Models of Government, Structural and Legal Institutions (Ural Branch of the Russian Academy of Sciences, Ekaterinburg, 2003) 476 p.

18. R. Iering, Struggle for the right (Vestnik Znaniya (VV Bitner), St. Petersburg, 1912) 72 p. 